\title{
How Currency Plays a Role in Spread of Contagious Diseases - Need for Clean Currency
}

\author{
Sudeep Vijay Limaye \\ Freelance Management Educator, India; \\ sudeeplimaye@yahoo.com
}

\begin{abstract}
Infectious diseases remain as the major causes of human and animal illness and mortality leading to significant healthcare expenditure in India. The country has experienced the outbreaks and epidemics of many infectious diseases. In recent times good successes have been achieved against the control of major epidemic diseases, but the challenges remain. Dynamic interplays of biological, socio-cultural and ecological factors, together with the economic exchange or transaction pose challenges with respect to the emergence and spread of infectious diseases. The important challenges faced in the control and prevention of emerging and re-emerging infectious diseases range from understanding the reasons of emergence to development of surveillance systems and also identifying and addressing the factors contributing to the spread. In his article an attempt is being made to look at the issue of spread of pathogens through the paper currency. Attempt has also been made to identify the sources and solutions to address the issue of pathogen transmission through currency notes.
\end{abstract}

Keywords: Currency Management, Hygiene, Soiled Notes, Pathogenic Contamination On Paper Currency, Virus

\section{Introduction}

The emergence of novel human pathogens and the emergence of several diseases have come in to sharper focus and has become a major concern of researchers and the governments in recent times. Apart from the scientific research related issues, the sharper focus has also been triggered due to rapid outbreak of pathogen related diseases. The health services and the related issues of spread of infectious diseases have to be also seen from a management perspective. This is required to understand the magnitude and the causes of the challenge and find solutions which are not considered in the medical research and are in the logistics and related management areas.

Communicable diseases are major causes of mortality in India. The impact of the communicable diseases mortality has a strong societal perspective. For a better understanding of it, we need to look at the enabling environment for spread and containment of communicable diseases. By that we mean the living or non-living mediums used by the pathogen to travel or spread.

Historically viral pathogens are known to cause outbreaks that have epidemic and pandemic potential. Government of India started a started a disease surveillance program in named as, The Integrated Disease Surveillance Programme (IDSP) in the year 2004. Under the program the government of India established a laboratory-based, IT-enabled system for surveillance of epidemic-prone diseases. The IDSP network reported a total of 1683 outbreaks of such diseases in the year 2017. The analysis of data as collected showed that 71 per cent of these outbreaks were caused by viral pathogens and 29 per cent were due to non-viral pathogens.

In the study of spread of communicable diseases the important aspect is the medium which contributes to the spread. One of the less noticed but highly exchanged non-livingcontact medium is currency Podhajny, M. R.

*Author for correspondence 


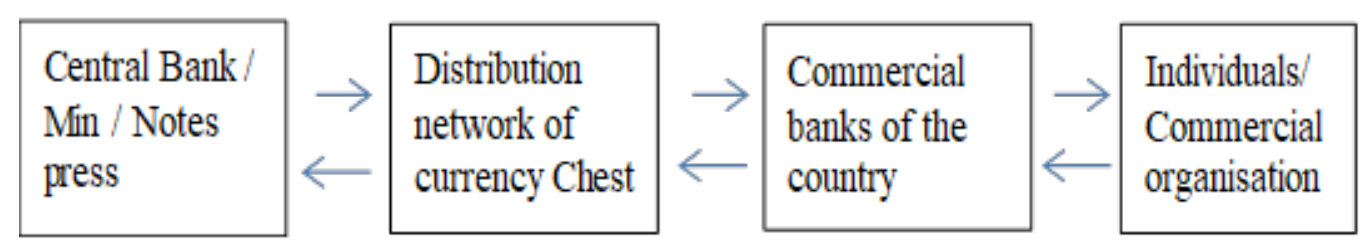

Figure 1. Closed loop of supply chain of currency.

(2004). As a means of economic exchange currency passes through multiple hands and contacts since the currency has a circular flow and there is a forward and backward motion of currency notes. (Figure 1) Ogbonda K H., Oku, I.Y., Okwelle, A.A., et al., (2012).

Currency notes are distributed to the public through banking channel these notes change hands in economic transaction and in the reverse flow the notes come back to banks which are either taken back for sorting and put back in circulation through bank branches or ATMs or are removed from circulation. This is done to withdraw the soiled or mutilated notes from circulation or for phasing out of the currency(Limaye S, 2011), Chinchorkar S, Limaye S (2017).

Indian economy is still considered as a cash economy and the daily transactions make the currency note to pass through many hands and pathogens get collected on them before the currency note actually gets deposited back in bank. There are nearly eleven lakh pieces of currency notes being stored in wallets or being exchanged in the market place (https://scroll.in/article/738482).

In an economy with cash transaction, currency note would pass through a very large number of hands. According to a report published by UK newspaper, the guardian in 2015, there is a way of estimating how many times each type of note changes hands. The newspaper quoting an analysis by On Stride Financial reported that a $£ 20$ note is typically used 2,328 times over an average lifespan of 113 months (10 years), similarly a $£ 10$ note is used 594 times in a lifespan of 36 months (3 years). Similarly the $£ 50$ note has a life span of 492 months (41 years). However, actually the currency note spends most of its life being in the people's purses or bags (https:// www.theguardian.com/news/datablog/2015/sep/04/).

Table 1. Bank notes in circulation in India as on $31^{\text {st }}$ march 2019

\begin{tabular}{|l|l|l|l|}
\hline \multirow{2}{*}{ Denomination } & \multicolumn{4}{|l|}{ Volume (Lakh pieces) } \\
\cline { 2 - 4 } & 2017 & 2019 & 2019 \\
\hline 2 and 5 & 115570 & 114250 & 113020 \\
\hline 10 & 369290 & 306450 & 312600 \\
\hline 20 & 101580 & 100160 & 87130 \\
\hline 50 & 71130 & 73430 & 86010 \\
\hline 100 & 252800 & 222150 & 200740 \\
\hline 200 & NA & 18530 & 40000 \\
\hline 500 & 58820 & 154690 & 215180 \\
\hline 1000 & 890 & 660 & NA \\
\hline 2000 & 32850 & 33630 & 32910 \\
\hline Total & 1002930 & 1023950 & 1087590 \\
\hline
\end{tabular}

Source: RBI annual report 2018 - 19 


\section{Problem Statement}

Scientific studies have confirmed the presence of various pathogenic bacteria on paper currencies (Girma G, 2014), Ogbu. O., Uneke, C. J. (2007), Lamichhane,J., Adhikary,S., Gautam, P., et al. (2009). The dominant contaminants types of pathogenic bacteria found on paper currency are fungal pathogens and parasite species Goktas, P., Oktay, G. (1992). (Umeh EU, Juluku JU, Ichor T, 2007). This indicates that the paper currencies could be one of the most potential medium to carry and transmit contagious diseases amongst the people Umeh, E. U., Juluku, J. U., Ichor, T. (2007), Ahmed, M. S. U., Parveen, S., Nasreen, T. et al., (2010). Investigations on the contamination of paper currencies with microorganisms are mainly seen from the medical field Goktas, P., Oktay, G. (1992). There is a general lack of literature on the logistics dimension of communicable diseases spread. Consequently, the shortage of such information contributes to the absence of public health policies regarding currency usage, handling and circulation.

This study attempts to study the logistics factors associated and identify the solutions to them.

\section{Methodology Used}

There is very a large body of literature available in medicine filed. The researcher has not been able to study research in the logistics and management aspect of diseases management. An attempt has been made in this article is to identify and highlight the logistical aspects of contagious diseases management. The researcher used a two pronged approach in identifying the magnitude of the issue of currency being an important medium in the spread of the infection. This was done by review of literature available on the risk of currency notes being the carriers of the contamination. Personal interviews were conducted with traders, individuals and bankers who handle currency in large quantum to identify the factors and solutions for those factors. The objective of the interviews was to identify the non-medical solutions to the issue of containing the spread.

\subsection{Literature Review- Risk of Handling Contaminated Paper Currency Notes}

Studies conducted by Ministry of health, government of India indicate that respiratory viral infections, arboviral infections and bat-borne viral infections are the three major categories of viral infections in India.

In Indian economy the currency note is handled by nearly all categories of people. This presents a particular risk to public health, as communicable diseases can spread through contact with non-living object and carry various deadly pathogenic microorganisms Debajit, B., Pratap, P., Tarun, K. (2012). Pathogenic microorganisms that survive on paper currency serve as a potential source of enter pathogens affecting food poisoning. This can be especially seen at street food vendors who tend to handle currency with the same hand through which the food is served. Such handling transfers bacteria from paper currency to humans. (Pope TW, Ender PT, Woelk WK, 2002)

The concern overspread of communicable diseases through the currency note has made some researchers call such a phenomena as the term "Dirty Money", Abrams, B. L., Waterman, N. G. (1972). Researchers at the Regional Sophisticated Instrumentation Center (RSIC) at the North Eastern University in Shilong, India, found that the bacteria from currency notes infect the body through cuts on the hands or when the hand touches the mouth, eyes or nose. The study examined Indian currency notes and found germs on the currency note which can cause Tuberculosis, Meningitis, tonsillitis, peptic ulcers, throat infections, genital tract infections, etc. Nagesh, B., Bhat, S., Asawa, K., et al., (2010).

Daily transactions have made the paper currency to pass through many hands and pathogens get deposited on them. Indian currency collected from bank, Municipal Corporation, food sellers, butchers, hospital, beggers, vegetable markets, pan shops, petrol pumps, grocery stores, bus, taxi and other public transport etc., showed that currencies used by public were found to be extremely contaminated with various pathogenic bacteria followed by the currency used by butchers and food sellers. (Alemu, Agersew, 2014)

Another factor seen in India and Asian countries is the practice of meat sellers collecting or paying money to buyers with hands that are contaminated with blood and animal wastes. Study has shown the presence of coagulatepositive staphylococci on the money surface handled by food sellers and handlers. (Brady, keller, 2000) Hosen, J.M., Sarif, D.I., Pahman, M., et al., (2006). Some other examples of unhygienic practices are, keeping money underneath their cloths with sweat; under the carpet or 
inside their socks. People also squeeze paper moneys and put them into their dirty pockets or keep it in polythene, cotton, leather bags in humid and dark conditions.

The contamination of paper currency could also lead to counting machine, currency chest or strong room becoming source or destination of contamination. This could lead to a health hazard to users in the bank Umeh, E. U., Juluku, J. U., Ichor, T. (2007). Studies conducted on currency counting machines and currency chest in banks have revealed the presences of various bacteria and fungi on them. The studies identified the possible causes of such contamination being the soiled notes, or because of the note passing through soil, clothing, food

Newspaper Deccan chronicle reported in their newspaper on 18 Nov. 2016 that the Dirty notes had given bank staffers 'cash allergy in Kurnool. The demonetization of currency by government of India had led to a very unique set of problems for bankers, namely cash allergy. Many bank staff members, who were counting huge amounts of currency since the demonetization for one week after the demonetization were found to be suffering from allergies and breathing problems besides rashes on their fingers. According to a branch manager of a nationalized bank, though cash counting machines were used, prolonged exposure to dust from the bundles was leading to these problems. It was reported by the newspaper Deccan chronicle that a manager of Indian Bank had developed rashes.

https://www.deccanchronicle.com/nation/currentaffairs/181116/dirty-notes-give-bank-staffers-cashallergy.html

or hands of users before currency being deposited in the bank Basavarajappa, K.G., Rao, P.N., Suresh, K. (2005), Prescott, L. M., Harley, J. P., Klein, D. A. (2005).

In a study conducted on Indian currency in the year 2013 it was found that microbial contaminants may be transmitted either directly or indirectly. That is through hand-to-hand contact or through food, water or other non-living objects. Paper Currency, can be contaminated by droplets during coughing, sneezing, touching with previously contaminated hands or other materials and placement on dirty surface. (Mohammed Rafiq Khan, Rajeswari K. Venkatesh, Nikhitha Ravi, Reshma Ravikumar and Santhosh Kumar, 2013)
Studies done in different parts of the world have also shown high rates of microbial contamination of currency notes Chase, M. (1998).

A study on USA Currency notes by Forensic Science International reported that $92 \%$ of the notes had traces of cocaine which is also a source of hepatitis C, Gadsby, P. (1998). Also the Centers for Disease Control and Prevention (CDC), USA estimates that 36,000 Americans die each year from flu-related causes. Among these deaths, $10 \%$ of people have been identified to have contacted the flu from paper currency, Pope, T. W., Ender, P. T., Woelk, W. K., et al., (2002). Similarly a research study on 5,000 banknotes in London in the year 2000 proved that $99 \%$ of the tested currency notes had traces of cocaine on them. It was estimated that out of 2,00,000 hepatitis $C$ cases record every year in the $\mathrm{UK}$, at least 5000 hepatitis $\mathrm{C}$ cases among that were caused because of currency notes. (http://www. gobyme.com/ feb.26 2016)

In a multi nation study conducted on India rupee, Bangladesh Teka, Iraqi and Ghanaian Currency, Alemu, Agersew in the year 2014 found that Notes were contaminated with $100 \%$ by pathogenic or potentially pathogenic bacteria (Alemu, Agersew, 2014).

In a study conducted on Nigerian currency it was identified that, contamination of different objects by pathogenic microorganisms is of public health importance. As the contaminated materials can be possible sources of transmission of such pathogens. The situation is more compounded by the incapability of the some of the governments to consistently withdraw old, mutilated paper currencies from the circulation. (Umeh EU, Juluku JU, Ichor T, 2007)

A study conducted in Ethiopia identified that people living in unhygienic conditions and following unhygienic practices contaminate the paper currencies with microorganisms. Some of these practices are not washing hands after using the toilet, counting paper currencies using saliva, coughing and sneezing on hands and not cleaning it later and placement or storage of paper currencies on dirty surfaces leads to the contamination and these currency notes later act as a vehicle delivering microorganisms to contaminate the hands of the next user. (Girma G, 2015)

From the research literature reviewed it can be summerised that there is present and imminent risk of contagion spread through the medium of currency in any 
economy or geography. The limiting factor for the same is the geopolitical geographical boundaries of the country as the particular currency note has circulation within a particular country. And the issues of contamination are difficult to address considering the universal hygiene factors.

\subsection{Findings and Suggestions}

As a result of the personal interviews it can be seen that the banks are the biggest handlers of currency note on India. As per the RBI press Release: 2019-2020/2052 dated $12^{\text {th }}$ march 2020 the currency with public money in India was about 2255771 crores. This was about 13.70 percent of the total M3 money supply in the country as on that date. This is a good indicator of the volume of currency being handled in the country. This also indicates that that there is a need to look at the logistics of currency as a place of intervention for arresting or controlling the currency becoming a medium of spread of contagion.

In the logistics of the currency in an economy, the two major stages are of storage and physical handling of currency. Interventions at both these stages would reduce the risk of contagion through the currency. The suggestions or recommendations can be put in to three broad categories or areas. They are, People, Process and technology.
The typical points of storage are the wallets, purses or other places by people, currency chest at banks and cash boxes of merchant establishments. While the typical physical handling points of currency are, cash counters at banks, payment points or counters of shops and other merchant establishments Mohammed Rafiq Khan, Rajeswari K Venkatesh, Nikhitha Ravi, Reshma Ravikumar and Santhosh Kumar, (2013).

It is suggested by experts that that there should be a periodic evaluation of microbial load and safety of paper currencies along with a sustained and regular awareness efforts to improve the poor hygienic practices being exercised while handling paper currencies at the bank branches and currency chest of the RBI, Talaro, K. P. (2005) Mohammed RafiqKhan, Rajeswari K Venkatesh, NikhithaRavi, Reshma Ravikumar and Santhosh Kumar (2013).

\subsection{People's Behavioral Change}

The government could work for awareness to people about the risk associated with soiled notes and handling of currency notes. Street food vendors and people should be made aware to avoid possible cross contamination between currency notes and foods and related hygiene Michaels, B., Gangar, V., Lin, C., et al., (2003). They should be educated and encouraged to use hand gloves

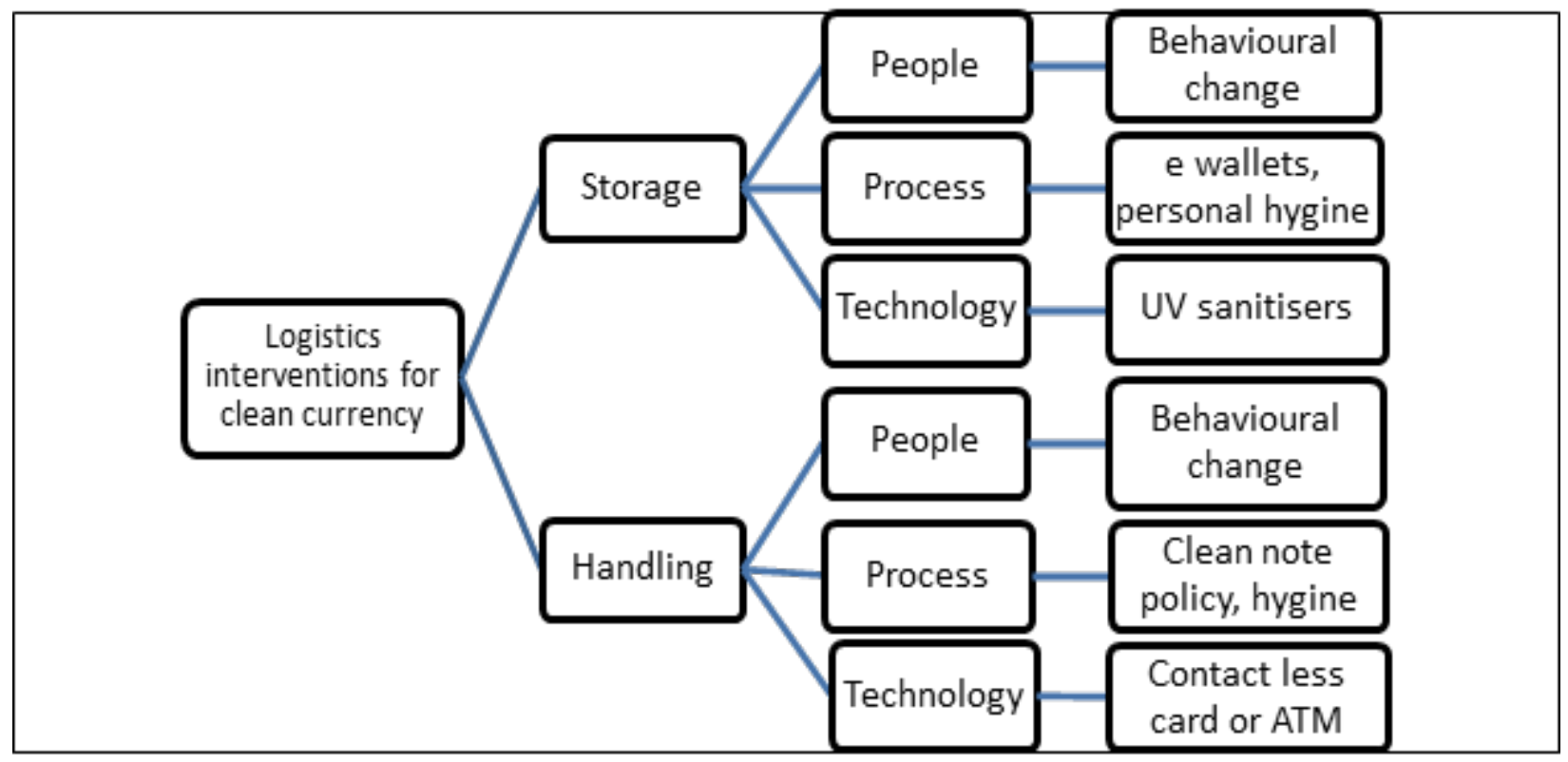

Figure 2. Logistics intervention for clean currency. 
for food delivery and a properly washed hand to exchange notes. A bulletin for the Australian Food Industry (2000). Also the habit of people of keeping money in clothes, handkerchiefs and in shoes should be discouraged. People should also avoid the use of saliva during counting of currency notes as well as desist from placing money in the mouth and biting off corners of currency notes Oyero, O. G., Emikpe, B. O. (2007).

\subsection{The Money Handling process has to Become Contactless}

People should be sensitized to ensure that they are handling the currency in a hygienic manner. They should be encouraged to adopt different payment systems created by RBI which are safe, secure and also hygienic.

Studies have shown that the longer the paper currencies remain in circulation, the more chance there is for them to become contaminated, and lower-denomination notes receive the most handling because they are exchanged more frequently. Reserve bank of India should have a strong and robust mechanism for withdrawal and disposal of soiled and mutilated currency. The clean note policy of RBI launched in early nineties and also in the financial year 2017-18 post demonetization should be extended to further to ensure no soiled notes remain in circulation.

Table 2. Disposal of soiled banknotes (April-March) (Million pieces)

\begin{tabular}{|l|l|l|l|}
\hline Denomination & $\mathbf{2 0 1 6}-\mathbf{1 7}$ & $\mathbf{2 0 1 7}-\mathbf{1 8}$ & $\mathbf{2 0 1 8}-\mathbf{1 9}$ \\
\hline 1 & 2 & 3 & 4 \\
\hline 2000 & NA & NA & 1 \\
\hline 1000 & 1514 & 6847 & 2 \\
\hline 500 & 3506 & 30024 & 15 \\
\hline 200 & NIL & NIL & NA \\
\hline 100 & 2686 & 105 & 3795 \\
\hline 50 & 778 & 83 & 835 \\
\hline 20 & 546 & 114 & 1163 \\
\hline 10 & 3540 & 497 & 6524 \\
\hline Upto 5 & 34 & 8 & 59 \\
\hline Total & 12503 & 27678 & 12393 \\
\hline
\end{tabular}

Source: RBI annual report 2018-19

Table 3. Payment infrastructure in India

\begin{tabular}{|l|l|l|l|l|l|l|l|l|}
\hline \multicolumn{9}{|l|}{ Payment System Infrastructures } \\
\hline \multicolumn{3}{|l|}{ No. of Cards } & \multicolumn{3}{|l|}{ No. of PPIs @ } & $\begin{array}{l}\text { No. of } \\
\text { ATMs }\end{array}$ & $\begin{array}{l}\text { No. of PoS } \\
\text { Terminals }\end{array}$ & $\begin{array}{l}\text { Bharat } \\
\text { QR @ }\end{array}$ \\
\hline & $\begin{array}{l}\text { Credit } \\
\text { Cards }\end{array}$ & $\begin{array}{l}\text { Debit } \\
\text { Cards }\end{array}$ & & Wallets @ & Cards @ & & & \\
\hline $\begin{array}{l}\text { No. } \\
\text { (Lakh) }\end{array}$ & $\begin{array}{l}\text { Vol. } \\
\text { (Lakh) }\end{array}$ & $\begin{array}{l}\text { No. } \\
\text { (Lakh) }\end{array}$ & $\begin{array}{l}\text { Vol. } \\
\text { (Lakh) }\end{array}$ & $\begin{array}{l}\text { Vol. } \\
\text { (Lakh) }\end{array}$ & $\begin{array}{l}\text { Vol. } \\
\text { (Lakh) }\end{array}$ & $\begin{array}{l}\text { Vol. } \\
\text { (Lakh) }\end{array}$ & $\begin{array}{l}\text { Vol. } \\
\text { (Lakh) }\end{array}$ & $\begin{array}{l}\text { Vol. } \\
\text { (Lakh) }\end{array}$ \\
\hline 8851.69 & 544.11 & 8307.59 & 17253.28 & 16243.87 & 1009.41 & 2.32 & 48.83 & 15.94 \\
\hline 8606.57 & 553.33 & 8053.24 & 17625.43 & 16615.68 & 1009.75 & 2.32 & 49.88 & 17.13 \\
\hline 8728.47 & 561.20 & 8167.26 & 17574.74 & 16575.31 & 999.43 & 2.33 & 49.47 & 17.79 \\
\hline
\end{tabular}

Source RBI annual report $2018=2019$ 
Paper currencies are one of the important sources for spread of infectious diseases in various countries due to their wide circulation. Thus it represents risks factor for health hazards to the community. Sustained efforts are required at every stage of the currency supply chain.

The government should look at the possibility of introducing washable plastic paper currencies, as has been done by countries like Australia and New Zealand. This would make the cleaning of currency possible without compromising the life spans of paper currency in the circulation.

\subsection{Technology has Answers}

Also, government should check the possible use of microbicide chemicals to be incorporated into the paper currencies while the printing currency or making of paper for the same. Banks should work on disinfection of currencies by ultraviolet light and chemicals means. This would decrease the risk of transmission of infection.

Encouragement to digital transactions by replacing the traditional methods of trading with payment gateways, electronic currency transactions such as ATM machine and encouraging the use of cards would be another good solution for the problem. This is important as Indian economy is still said to be a cash economy with a large amount of transactions happening is cash.

\section{Conclusion}

Based on the evidence of the studies conducted, we can summaries that paper currency is generally contaminated with pathogenic microorganisms and this contamination is in its journey of use and may play a role in the transmission of harmful microorganisms and therefore represents risks and public health hazards to the community and individuals.

One of the common links in the health epidemics that have hit the global human race has been the issue of hygiene. Be it the SARS family of diseases or other like TB, Malaria. This paper is an attempt to identify and highlight the non-medical factors and their importance in the activity of health management, hygiene and its linkage to currency management. It is suggested that people should keep strict adherence to hygienic practices before handling food and water after contact with paper currency, Michaels, B., Gangar, V., Lin, C., et al., (2003). Measures such as thorough hand washing with soap or sanitizers after handling currency notes by cashiers in bank branches and also in commercial establishments will help in reducing the risk of contamination and spread Prescott, L. M., Harley, J. P., Klein, D. A. (2005).

This article is based on existing research literature and on personal interviews of selected individuals. There is a need for conducting more detailed study to validate the suggestions made in the study and also to identify the sources of contamination and also of possible remedial measures to contain or control the same. It is identified that technology has an important role to play in identifying the areas of improvement and prevention of contamination during the journey of currency in the economy.

It is also suggested that the government of India should include hygiene of currency in its Swaccha Bharat (clean India) initiative. The government initiative on clean India has to start drilling down to the specifics and the cleaning the currency of harmful pathogen would be an important step in elimination of the source of contamination and spread of diseases.

By addressing and source of spread of virus the country as a whole would be eliminating the high cost of health related expenditure at both individual as well as governmental level Laxminarayan, R., Malani, A. (2007). This would also provide the nudge for the society to develop a hygienic and healthy way of life. This should really be the true objective and goal of a cleaner India.

\section{References}

1. Girma, G. (2015). Health risk associated with handling of contaminated paper currencies in circulation: A review. J Food Nutr Sci, 2(2), 1-6. https://doi.org/10.15436/23770619.15.014.

2. Podhajny, M. R. (2004). How dirty is your money? Paper, Film and Foil Converter (PFFC). Penton Media Inc 2300, 60611-3698.

3. Hosen, J.M., Sarif, D.I. \& Pahman, M., et al. (2006). Contamination of coliforms in different paper currency notes of Bangladesh. Pak J Biol Sci, 9(5), 868-870. https:// doi.org/10.3923/pjbs.2006.868.870.

4. Ogbu. O. \& Uneke, C. J. (2007). Potential for parasite and bacterial transmission by paper currency in Nigeria. J Environ Health, 69(9), 54-60. 
5. Oyero, O. G. \& Emikpe, B. O. (2007). Preliminary investigation on the microbial contamination of Nigerian currency. Int J Trop Med, 2(2), 29-32.

6. Ogbonda, K. H., Oku, I. Y. \& Okwelle, A. A., et al. (2012). The incidence of human disease-causing fungi on Nigerian paper money. Int J MicrobiolImmmunol Res, 2(1), 6-10.

7. Chase, M. (1998). Add to the evil of money the fact it carries many germs. Dow Jones News.

8. Sudeep, L. (2011). Study on Currency logistics and challenges in India and China. Matrix Business Review, 1(1), 134-141.

9. Abrams, B. L. \& Waterman, N. G. (1972). Dirty Money. J Am Med Assoc, 219(9), 1202-1203. https://doi.org/10.1001/ jama.219.9.1202. PMid:4621943

10. Lamichhane, J., Adhikary, S. \& Gautam, P., et al. (2009). Risk of handling paper currency in circulation chances of potential bacterial transmittance. Nepal J Sci Technol, 10, 161-166. https://doi.org/10.3126/njst.v10i0.2952

11. Umeh, E. U., Juluku, J. U. \& Ichor, T. (2007). Microbial contamination of Naira (Nigerian Currency) notes in circulation. Res J Environ Sci, 1, 336-339. https://doi. org/10.3923/rjes.2007.336.339

12. Girma, G., Bacha, K. \& Ketema, T. (2014), Microbial load and safety of paper currencies from some food vendors in Jimma Town, Southwest Ethiopia. BMC Research Notes, 7, 843. https://doi.org/10.1186/1756-0500-7-843 PMid:25424723 PMCid:PMC4255439

13. Alemu, A. (2014). Microbial contamination of currency notes and coins in circulation: a potential public health hazard. Biomedicine and Biotechnology, 2(3), 46-53.

14. Basavarajappa, K.G., Rao, P.N. \& Suresh, K. (2005). Study of bacterial, fungal, and parasitic contamination of currency notes in circulation. Indian J Pathol Microbiol, 48(2), 278279.

15. Brady, D. \& Kelly, J., (2000). The assessment of the public health risk associated with the simultaneous handling of food and money in the food industry. Emergence of Infectious Disease, 6, 178-182.

16. Laxminarayan, R., Malani, A. (2007). Extending the cure, policy responses to the growing threat of antibiotic resistance.

17. Nagesh, B., Bhat, S., Asawa, K., et al. (2010). An assessment of oral health risk associated with handling of currency notes. Int J Dental Clinics, 2(3), 14-16.

18. Pope, T. W., Ender, P. T. \& Woelk, W. K., et al. (2002). Bacterial contamination of paper currency. South Med J, 95(12), 1408-1410. https://doi.org/10.1097/00007611200212000-00011. PMid:12597308
19. Khan, M.R, Venkatesh, R. K., Ravi, N., Ravikumar, R. \& Santhosh Kumar. (2013). Assessment of microbial contamination of Indian paper currency notes in circulation. International Journal of Recent Scientific Research, 4(10), 1516-1518.

20. Goktas, P. \& Oktay, G. (1992). Bacteriological examination of paper money. Mikrobiyol Bull, 26(4), 344-348.

21. Chinchorkar, S. S. \& Limaye, S. (2017). Product design deliberations for circular SCM to promote green SCM. IMR (Indira Management Review), (11)2.

22. Ahmed, M. S. U., Parveen, S. \& Nasreen, T. et al. (2010). Evaluation of the microbial contamination of Bangladesh paper currency notes (Taka) in circulation. Advanced Biological Research, 4(5), 266-271.

23. Michaels, B., Gangar, V. \& Lin, C., etal. (2003). Uselimitations of alcoholic instant hand sanitizer as part of a food service hand hygiene program. Food Serv Technol, 3(2), 71-80. https://doi.org/10.1046/j.1471-5740.2003.00067.x

24. Talaro, K. P. (2005). Foundations in microbiology. 5th (edn). Mc- Graw-Hili Companies Inc.

25. Gadsby, P. (1998). Filthy lucre: bugs, drugs and grime hitch a ride on the back of every buck. Discover, 19: 76-84.

26. Debajit, B., Pratap, P. \& Tarun, K. (2012). Paper currencies, a potential carrier of pathogenic microorganisms. Int $\mathrm{J}$ Appl Biol Pharmaceutical Technol, 3(1), 23-25.

27. A bulletin for the Australian Food Industry. (2000). Money handling in food service operations: Food safety and hygiene.

28. Prescott, L. M., Harley, J. P. \& Klein, D. A. (2005). Microbilogy 6th Tim Mc Graw Hill Co. New Delhi, India.

29. Available from: http://www.who.int/gho/ mortality_burden_disease/global_burden_disease_death_ estimates_sex_age_2008.xls

30. Available from: https://www.scienceabc.com/humans/ germs-bacteria-ridden-currency-notes-dirty- money. html Beware! The rupee notes in your wallet are carrying disease-causing microbes, warns study

31. Available from: https://scroll.in/article/738482/ beware-the-rupee-notes-in-your-wallet-are-carryingdisease- causing-microbes-warns-study Government study says currency notes carry disease-causing micro-organisms

32. Available from: https://www.researchgate.net/ publication/260872240_Microbial_contamination_of_ Indian_currency_notes_in_circulation Scientists say that currency notes carry micro-organisms that spread diseases

33. Available from: http://www.dnaindia.com/india/ report-scientists-say-that-currency-notes-carry-microorganisms-that-spread-diseases-2113982 
34. Available from: https://www.deccanchronicle.com/nation/ current-affairs/181116/dirty-notes-give-bank-stafferscash-allergy.html

35. Available from: https://www.ncbi.nlm.nih.gov/pmc/ articles/PMC6676836/

36. Available from: https://www.wsj.com/articles/ fed-delays-processing-dollar-bills-from-asia-amidcoronavirus-fears-11583512719
37. Available from: https://www.theguardian.com/news/ datablog/2015/sep/04/how-often-uk-banknotes-changehands

38. Available from: http://www.gobyme.com/ dirty-contaminated-money-diseases-spread-throughmoney-currency-notes/

39. Microbial contamination of Indian currency notes in circulation. Available from: https://funfactz.com/ technology-facts/hitachi-sterilizing-atm/ 